Jurnal Pendidikan Bahasa dan Sastra Indonesia is licensed under

A Creative Commons Attribution-Non Commercial 4.0 International License

\title{
Cultural Value in Mantra Menyapih in Village Communities: Literature Function Study
}

\author{
Marwanto \\ Faculty of Education and Teachers Training, IAIN Salatiga, Indonesia \\ E-mail: marwanto@iainsalatiga.ac.id
}

\begin{abstract}
In fact, the tradition of weaning spells is still developing and surviving to this day, the existence of this tradition is indeed needed by the community for their children to suckle their mothers. Stopping the child from sucking on his mother again is indeed quite difficult, so the people bring their children to suwuk experts, in this case dukun, kyai and local leaders. Suwuk expert will say rapalan or mantra in this case. The purpose of this study is to describe cultural values in the weaning mantra on rural communities: the study of literary functions. This study uses an observation method with ordinary observations because of observations carried out by researchers without being involved in direct contact with the actors (informants) who were the target of the research. The results of this study, people still use the services of expert suwuk in this case can $d u k u n$, suwuk experts, or traditional leaders, so that their children stop asking for milk.
\end{abstract}

Keywords: Suwuk; Mantra; Nyapeh; Netek; Kyai; Shaman

\section{INTRODUCTION}

One day a housewife was confused about what to do to stop her child from crying, various ways were done both seducing her, carrying her, giving her toys, even various ways of doing it, but her child still kept crying asking for her mother to give her breast milk (breast milk). The need for breast milk for children is very important especially for village people who are still difficult to buy milk for their children. Milk is a rare item and has a higher dignity than rice for villagers. Apart from the increasingly high cost of living, people keep trying so that the needs of their children are fulfilled, then the philosophy of manganese or manganese important singles gather as a foundation that many children can cause sustenance easily achieved or obtained, according to their understanding that every burden increases, then Even though the acquisition will increase, it means that the more children there are, the more / more work / people working and if more and more are working, of course the income earned in that family will increase.medan

Culture was a human creation that took place in life and their society (Bahar \& Teng, 2017). Whereas, it defines as a way of thinking and feeling (spirituality) in life that forms social unity in space and time (Gazalba, 1979). Jenks' sense of culture is also conveyed, namely: 1) Cognitive category culture; culture is a general statement about ways of thinking, 2) Culture as a collective category; culture encourages intellectual, and moral conditions in society, 3) culture as a concrete and descriptive category; namely culture is a collective unity in the work of art and intellectuals in a society, and 4) Culture as a social category; culture is the whole way of life of humans (Jenks, 1993).

Culture is always related to traditional arts or technology, because culture cannot be present without the works of the ancestors which are called traditional technology (Saliyo, 2012). Culture is a system of knowledge that is an idea or idea contained in the human mind and culture that is abstract in nature (Khairi Abu Syairi, 2013). Culture in the broadest sense is all human activities and actions carried out in an effort to find adjustments and perfection of life in the world (Hun, 2012). All that is produced and created by humans to fulfill life is called culture or culture (Bahar \& Teng, 2017). A culture cannot be separated from the pattern of community activities (Prayogi \& Daniel, 2016). Culture is a basic assumption and values, orientation to life, beliefs, policies, procedures and conventions of behavior that are owned by a group of people, and affect the behavior of everyone (Spencer-Oatey, 2012). Cultural values are ingrained values that are difficult to replace with other values (Rukesi \& Sunoto, 2017).

Cultural values are concepts that live in the minds of most people about things they consider very valuable (Koentjaraningrat, 1990). Cultural values based on the pattern of human relations, namely the relationship between humans and God, nature, society, other humans, and themselves (Djamaris \& dkk, 1996). Whereas Cultural values are the most abstract level of adat which consists of conceptions, which live in the minds of most citizens, regarding things that they must consider very valuable in life and serve as the highest guideline for human behavior (Ermina Istiqomah). 
Explains that literature is an oral or written work that has superiority in originality, artistry, beauty in content, and expression (Sudjiman, 1986). Spell as one of oral literature namely folk poetry, the sentence is bound (Danandjaja, 1984). Spells in Indonesian society are known as rapalan or sayings in certain languages for certain purposes and purposes (Sorayah, 2014). The world of spells at this time is indeed many that have been left behind even though this is a hereditary inheritance of the people of Indonesia.

Much research has been done on culture, but those that specifically examine cultural values in Weaning Mantra have not been there before. The study of "Community Empowerment in Plempoh Cultural Tourism Village", only examines cultural tourism villages (Hidayat, Rahmanita, \& Hermantoro, 2017), including research "Cultural strategies of development: implications for village governance in China", describing cultural development strategies (Oakes, 2006). Research on values was only found in the research "Significance of cultural values in asset portfolio of rural communities", but examined the cultural value of rural portfolios (Daskon, 2015). Research on mantra cultural values has only been found in research on cultural values of farming spells (Rukesi \& Sunoto, 2017) and local wisdom in Samin community spells (Rizal, 2015).

For a woman to close her genitals is an obligation when she is not married, but on the contrary when she is a mother, when her child whines and asks for milk / breast milk wherever she is, a mother will take it out because of the need for her child. Services that are satisfying for the needs of their children must indeed be put forward and vice versa, a mother will feel embarrassed if her child cries and cries to be heard by her neighbors.

Breastfeeding a child cannot be forever, meaning that at any time it must be stopped. Stopping children from netek is not easy, either because of age or other causes. This is the basis of the problem in this study. The purpose of this study is to describe cultural values in the mantra of reciting the village community: the study of literary functions.

\section{METHODS}

The author uses the observation method / field observation method. There are four kinds of observation methods, namely ordinary observation, controlled observation, involved observation, and full or complete observation. In this study the author uses ordinary research methods, ordinary research methods are observations carried out by researchers without being involved in direct contact with the actors (informants) who are the target of the research (Sutopo, 2002).

The subject of this research is the people who do the singing, while the object under study is the mantra tradition of invading rural communities, while these data are obtained through direct interviews with people who carry out the tradition of suwuk.

\section{RESULTS AND DISCUSSION}

This research was conducted in the village of Mantran. Mantran is a hamlet on the slopes of Andong Mountain, Girirejo Village, Ngablak District, Magelang Regency. Its location on the slopes of the mountains makes people in their lives mix vegetables and tobacco as commodities of daily life. People live beautifully and are comfortable with their habits every day. Depart early in the field and go home in the afternoon. Eating and worship are usually done in each field because the place is far away.

The culture of mantra weaning in the language of the Mantran people is suwuk nyapeh (Javanese) or some people often refer to mareni. The word weaning in an Indonesian dictionary means stopping the child from breastfeeding his mother (Setiawan, n.d.). This is done if a child turns two years old or over one year of age. The reason is that I have to work in the fields. A woman also does the same work as her husband. When leaving for the field a husband will bring fertilizer in his head and hoe on his shoulder and still have to carry a sickle, the back of the tool has been attached to spray the plants. his wife also did not miss, while leaving with his head carrying a basket filled with fertilizer (nyunggi), carrying his child, and still having to bring provisions for lunch. Taking grass, carrying manure with a place above the head, and spraying plant pests is an inseparable job in his daily life for a woman.

According to Koentjaraningrat, culture can be recognized as having at least three forms, (1) being as a complex idea, concept, and human mind, (2) being a complex of activities, and (3) being an object means culture or culture as a whole aspects of human life both material and non-material or culture will develop from a simple stage to a more complex stage (Koentjaraningrat, 1993).

Tradition is culture, many traditions are carried out as routine activities in Indonesian society, both in the form of ancestral cultural heritage and those that occur due to time travel and environmental influences, such as the tradition of speaking well to parents (uploading), building houses together- the same or what is now famous for mutual cooperation, village birthdays and so on. This tradition is still strong and entrenched as cultural wealth in Indonesia. Of course, among the many places there are variations and differences that are local. The author takes this theme as an attempt to reintroduce Indonesian culture. For example in this discussion is suwuk. Suwuk is a tradition so that children stop breastfeeding their mothers. A mother will stop breastfeeding her child if, 1) a two-year-old child has not stopped breastfeeding her, 2) breastfeeding has not come out again or indeed she does not want to leave, 3) stop breastfeeding because the child's health is afraid to be disturbed, and 4) someone does not want to breastfeed her child.

When it happens as above, a mother will go to a dukun or a smart person who is considered capable or expert to be able to help her so that her child does not suckle / suckle again. According to the large Indonesian dictionary a Shaman is a person who is an expert in treating diseases or mental disorders with incantations or also referred to as 

child immediately forgets and does not want to suckle his mother again.

Hamlets or villages call it a suwuk/suwuk an expert. Suwuk is a service job that is basically to help people who need it. The habit of people going to shamans is inseparable from the lack of knowledge and at the same time the lack of socialization of health in the community, besides that the community is reluctant to go to the Community Health Center or local Midwives for various reasons such as shame and something that will happen to them and their children called kualat. Parents will usually say this "Grandma says that nek kowe ra manut wong tuo, sak karepmu, yeng engko, ono opo-opo ojo disalahke wong tuomu, from these words when things really happen that are not wanted, because they do not obey advice parents, the person is called kualat. Trust in this matter is indeed deeply rooted in society, and is very difficult to eliminate.

The tradition of surviving is none other than that this tradition of suwuk can help the mother stop her child from breastfeeding, besides the suwuk has no direct negative effect on the mother and child who are suwuk, this is evident from the lack of direct contact between the shaman or suwuk expert to the child who will be suwuk and also there is no direct contact with the mother whose child will be suwuk.

The author can draw conclusions from the opinion of mothers who are not married in the above mentioned way by giving a kind of betadine, turmeric, mahogany and lipstick on the nipple of mother's milk, according to what mothers do for their children, it can cause children to be scared and traumatized, even though positively the child no longer wants or can stop breastfeeding his mother. There are six things that make the tradition of suwuk still survive because this tradition is very easy to do, this tradition has no direct effect on children or mothers who want their children to be suwuk, this tradition does not require much money, this tradition also does not require conditions various kinds, it is very easy to find or meet a dukun or suwuk expert in the village, this tradition does not interfere with the health of the child or mother, because no one has ever experienced a child whose health has been disrupted after the child is suwuk, and cultural heirs are still maintained.

Mantra itself is one form of oral literature. It is a part of old literature because it contains emotional elements, elements of beauty in the form of rhythm, and elements of moral value because the mantra is assimilation between language and trust (Rukesi \& Sunoto, 2017). Nyapeh or weaning is an activity to stop children from breastfeeding their mothers. In this connection weaning mantra can be interpreted as an activity to stop a child from breastfeeding his mother by going to a dukun or suwuk expert or mantra expert, so that the child does not suckle his mother back.

Classify cultural values based on patterns of human relations, namely the relationship between humans and God, nature, society, other humans, and self (Djamaris \& dkk, 1996).

\section{The results of interviews with the Mantran hamlet community about weaning culture.}

The mantra tradition is done from generation to generation. This tradition is done so that it is given safety or people often say refuse reinforcements or as protection, both for children, parents, and families who do suwuk. This research was conducted in the village of Mantran, Magelang regency. The author took 10 samples by interviewing people who had done the tradition of suwuk on their respective bases and also five samples from people who had not done the tradition of suwuk anymore.

According to the people who have carried out suwuk, it can be mentioned as follows, Lasiem (hamlet of west Mantran, village of Girirejo) recounts his experiences when nyuwuk his child. Suwuk is carried out at the same time as the day of birth of the child, according to the age desired by parents, can be at the age of one year or two years. When going to the Shaman the parents bring food that their children really like as a condition that what the child will remember is the food, not the milk again. A few moments later the Shaman reads the Mantra or prays for a moment and blows the wind on the child's forehead or head. Aside from that, dukun suwuk also advised the mother of the child to give the water that had been prayed for to wash her face so that when the child asked for milk / milk they would not want it or forget it, and instead the food instead.

Lastri (hamlet of Mantran Wetan, Girirejo village) according to the story, before meeting with a dukun, we must have an appointment first, and on the appointed day or agreed upon a dukun will come to the house of the child who will be suwuk. The child's mother was asked to prepare one glass of water. The suwuk expert holds the water inside the glass, then momentarily recites the mantra, commits (whatever the cleric reads doesn't know) after that, the water in the glass is blown three times. The ritual of suwuk was finished, in three days later the child had forgotten himself and did not want to suckle his mother again.

Ngarmi (hamlet of west Mantran) is different from the story of this mother, according to her, suwuk is done when a toddler is two years old, and takes it to a traditional figure in the community by bringing the child's favorite food or drink. The community figure casts a spell in front of the food and drink, then gives it to the child. on the third day of the implementation of the suwuk the child was not clean anymore.

Yuni (West Mantran) a two-year-old child is brought to a dukun or kyai, by giving food and a glass of water that has been given a mantra / prayer and then food and a glass of water is given back to the person to give to his child who wants to be suwuk. Three days after my child was sued, my child no longer asked for breastfeeding until now he was four years old.

Poniyem (hamlet east Mantran) tells us that children aged 18 months or 20 months can already be suwuk, so that children do not suckle again on their mothers and so that children can quickly become acquainted with toys, drinks, and fruits. If the child still wants to feed give food such as biscuits, toys such as cars, and buy the child's favorite milk 
that has been given a spell by the shaman / smart person / local village chief until the child forgets to ask for his mother's milk.

Sukarjo (hamlet of west Mantran) told me, I once took my wife and child to a dukun suwuk, there by a dukun, the dukun muttered, my child was read to something and then his forehead was blown three times. Shamans advise about three days later the child will forget himself and will not clean his mother again.

Kemis (hamlet of west Mantran) also once delivered his children and his wife, according to his story in my village the tradition of suwuk is still being carried out, even though it was a legacy of the community. Children who are approximately 24 months old are taken to a traditional leader in the area where they live, then by a traditional leader / leader read a prayer/ mantra, a few moments later the child will forget himself and will not want to suckle / suckle his mother again.

Ngateman (hamlet east Mantran) tells us that when he delivered his child and wife, suwuk was a tradition carried out by rural communities on every 22 -month-old child to eliminate the habit of dependence on children to suckle their mothers. Every baby who has been done suwuk will stop from dependence on breastfeeding his mother. A shaman in front of the baby recites something (his mouth is muttering) reciting mantras or prayers. This tradition is carried out by the community led by a person considered smart by the community.

Parini (hamlet of east Mantran) has a different experience from what was conveyed by this mother, suwuk is a termed treatment and a way to separate her child from drinking breast milk again. Her one-year-old child was brought to a dukun and there was given water that had been spelled out by the dukun. for about three days his daughter didn't want to suck again, and this was also done to her number two son, the same son was the same, but the difference in the age of his son was two years, and his feelings were the same.

Wakidah (hamlet of east Mantran) said that when he delivered his son to a traditional shaman, it was done at the house of a mother who would carry out the tradition, but now a mother who would take her child in my area, a mother would bring her child to the parents' house to carry out the mareni. This tradition occurs in children who are old enough or indeed I at that time wanted my child not to suckle me again. There I brought my child's favorite food and after that my child was given a spell, four days later my child did not want to suckle me again.

\section{Cultural Value in Weaning Charms in Mantran Village Communities}

Culture as a whole of the results of mind and works (Koentjaraningrat, 2003). Classify cultural values based on patterns of human relations, namely the relationship between humans and God, nature, society, other humans, and self (Djamaris \& dkk, 1996).

Cultural values that relate to humans and God
In relation to God the community practices according to Islamic beliefs. They continue to perform prayers, fasting, recitation, and prayers to people who have died. Islamic tradition is also an activity such as commemorating Islamic holidays. But the traditions are still a habit in their daily life such as Saparan, Gimbal Shaving, Birth, Death, Circumcision, and Marriage. They still hold strong and carry out the tradition. The community has traditionally continued to carry out local values that are believed to be true and have become a lifeline that has been passed down from generation to generation (Efendi, 2016).

Suwuk weaning tradition is a tradition that still survives. This is done as an effort to surrender to God, surrender or surrender to surrender fully before, process, and results only to God. Humans only try. This activity is always done by praying. Prayer is basically intended for the people who carry out this activity to be saved before, during suwuk, or after committing suwuk. The value of trust in the occult also adorns this tradition, doing this tradition is part of the belief that is still maintained. Javanese people often say kualat, something can happen if they do not do this tradition.

\section{Cultural values that relate to humans and nature}

Humans cannot separate themselves from nature. That means that humans always need nature in their lives. The relationship between humans and nature is the most fundamental relationship in human life. This nature was created by the God as a counterweight and companion of humans in the process of life. Humans must always respect and maintain among fellow living beings for a harmonious survival.

The weaning tradition is always related to nature, in this case the occult. Belief in the existence of supernatural beings is one of the ways humans live with nature. Suwuk nyapeh tradition is an activity that is believed because of the belief in the existence of the occult. A very strong belief causes people to always adhere to traditional customs as the tradition of suwuk nyapeh this. They are aware and that they are safe in their lives. The existence of nature is very much needed by humans.

\section{Cultural values related to humans and society}

The tradition of mutual cooperation in a hamlet is still very intense. Extraordinary kinship is the driving force. The local communities have high social solidarity and have a noble culture, such as mutual cooperation, deliberation, and harmony (Efendi, 2016). In the tradition of suwuk nyapeh this also does not escape because of mutual help to help. A suwuk shaman does not get money in the form of money, but usually people bring something, the produce from the garden as a feeling or a sign of gratitude. Extraordinary respect, the value of a shaman suwuk includes having a high position in the strata of his life.

\section{Cultural values related to humans and other human beings}

This cultural preservation effort must be pursued in various ways, especially with the development and influx of foreign language globalization. Incoming culture must be 
dealt with wisely as a progress and development of culture, rather than vice versa it will kill and eliminate local culture. Suwuk tradition is one of the local cultures that can still survive to this day.

This suwuk tradition occurs because of the relationship between humans and other humans, in this case with the shaman suwuk. Before committing suwuk there are usually certain conditions that must be prepared in accordance with the direction of the dukun suwuk. Roses, foods that are liked by children, water and others.

\section{Cultural values that relate to humans and themselves}

Suwuk nyapeh tradition is a hereditary tradition. This is done as a form of human effort or hard work so that stopping children from breastfeeding is always given safety. This effort requires patience, as a value of human culture, because in suwuk events it can be completed immediately or it can wait for days, one, two, or maybe more.

Children who are weaned can be cured immediately and cannot suckle their mothers back, but some will take time. This is what requires a process of patience. It could be that the child will cry, heat, or something else can happen.

\section{CONCLUSIONS}

Suwuk is a tradition so that children stop breastfeeding their mothers. A mother will stop breastfeeding her child if the child is old. Communities, especially mothers, usually use the services of suwuk experts such as dukun, kyai or traditional leaders who are believed to be able to help them in an effort to stop or mareni their children who keep asking for milk to them.

In this study, based on the study of (Djamaris \& dkk, 1996) classifying cultural values based on patterns of human relations, namely the relationship between humans and God, nature, society, other humans, and themselves (Rukesi \& Sunoto, 2017). As a discussion in this study, namely, the cultural values that relate between humans and God, the cultural values that relate between humans and nature, cultural values that relate to humans and society, cultural values related to humans and other human beings, and related cultural values between humans and themselves.

\section{ACKNOWLEDGMENT}

We would like to thank Faculty of Education and Teachers Training, IAIN Salatiga has supported the completion of this paper

\section{REFERENCES}

Bahar, H. M., \& Teng, A. (2017). FIlsafat Kebudayaan dan Sastra (dalam Perspektif Sejarah). Ilmu Budaya, 5, 6975.

Danandjaja, J. (1984). Folklor Indonesia, Ilmu Gosip, Dongeng, dan lain-lain. Jakarta: Grafiti Press.

Daskon, C. D. (2015). Significance of cultural values in securing asset portfolios of rural communities. Sri
Langka Journal of Social Science, 38(1), 31-50.

Djamaris, E., \& dkk. (1996). Nilai Budaya dalam Beberapa Karya Sastra Nusantara: Sastra Daerah di Kalimantan. Jakarta: Pusat Pembinaan dan Pengembangan Bahasa Departemen Pendidikan dan Kebudayaan.

Efendi, A. (2016). Implementasi Kearifan Budaya Lokal pada Masyarakat Adat Kampung Kuta sebagai Sumber Pembelajaran IPS. Sosio Didaktika: Social Science Education Journal, 1(2). https://doi.org/10.15408/sd.v1i2.1263

Gazalba, S. (1979). Kebudayaan Sebagai Ilmu. Jakarta: Pustaka Antara.

Hidayat, A., Rahmanita, M., \& Hermantoro, H. (2017). Community Empowerment in Plempoh Cultural Tourism Village. Tourism Research Journal, 1(December). https://doi.org/10.30647/trj.v1i1.11

Hun, K. Y. (2012). Pembelajaran Bahasa Indonesia di Perguruan Tinggi Korea: Sarana Menjelajahi Dunia Global. Proceeding International Seminare, 23-31.

Jenks, C. (1993). Culture (Konsep Budaya) Oleh: CHRIS JENKS Penerjemah: Arie Setyaningrum Pamungkas Editor : Novi Kurnia BUDAYA. Salford.

Khairi Abu Syairi. (2013). Pembelajaran Bahasa dengan Pendekatan Budaya. Dinamika Ilmu, 13(2), 174-188.

Koentjaraningrat. (1990). Sejarah Teori Antropologi II. Jakarta: UI Press.

Koentjaraningrat. (1993). Sejarah Teori Antropologi I. Jakarta: UI Press.

Koentjaraningrat. (2003). Pengantar Antropologi I. Jakarta: Rineka Cipta.

Oakes, T. (2006). Cultural strategies of development: implications for village governance in China. The Pacific Review, 19(1), 13-37. https://doi.org/10.1080/09512740500417616

Prayogi, R., \& Daniel, E. (2016). Pergeseran Nilai-Nilai Budaya Pada Suku Bonai Sebagai Civic Culture Di Kecamatan Bonai Darussalam Kabupaten Rokan Hulu Provinsi Riau Ryan Prayogi, Endang Danial. Humanika, 23(1).

Rizal, M. S. (2015). Karifan Lokal dalam Mantra Masyarakat Samin. Bastra, 2.

Rukesi, \& Sunoto. (2017). Nilai Budaya dalam Mantra Bercocok tanam Padi di desa Ronggo, Kecamatan Jaken, Kabupaten Pati, Jawa Tengah. Basindo, 1(1), $25-45$.

Saliyo. (2012). Konsep Diri dalam Budaya Jawa. Buletin Psikologi, 20(2), 26-35.

Setiawan, E. (n.d.). Kamus Besar Bahasa Indonesia (Online). Jakarta: Badan Pengembangan dan Pembinaan Bahasa, Kemdikbud (Pusat Bahasa).

Sorayah, Y. (2014). Funsi dan Makna Mantra Tandur di Desa Karangnunggal Kecamatan Cibeber Kabupaten Cianjur. Bahtera Sastra, 2.

Spencer-Oatey, H. (2012). What is Culture? In Global PAD Core Concepts.

Sudjiman, P. (1986). Kamus Istilah Sastra. Jakarta: Gramedia. 
Jurnal Pendidikan Bahasa dan Sastra Indonesia

Volume 4 Nomor 2 September 2019. Page 121-126

p-ISSN: 2477-5932 e-ISSN: 2477-846X

Sutopo. (2002). Metode Penelitian Kualitatif: Teori dan Aplikasi dalam Penelitian (Cetakan Pe). Surakarta: UNS Press.
Tim Penyusun. (2008). Kamus Besar Bahasa Indonesia (Offline). Jakarta: Pusat Bahasa. 